\title{
Women as Icons in the Economic Development of Kuron Pottery Making In Sabah
}

\author{
Nurul Aisyah Othman, Humin Jusilin, Salbiah Kindoyop \\ Borneo Heritage Unit Research, University Malaysia Sabah
}

\begin{abstract}
There is no doubt in this age the role of women in economic development is no longer doubted at present and in fact able to match the capabilities of men. The involvement of women in the effort to provide their contributions and services to the country is not a small sacrifice. There are many things that they need to manage and at the same time balance their career as well as their family lives. This can be seen through the economic development they have achieved particularly in producing the kuron, a Sabah traditional pottery. This type of traditional pottery is usually made by women who are creative in conveying their ideas from a technical point of view, design and unique motifs. The purpose of this research is to highlight the skills and abilities of women as icons in the production of traditional pottery crafts. The researchers look at the women icon in detail using the feminist idea introduced by June Hannam (2007) that emphasizes on the current competitiveness and position of women in improving economic development. The aesthetic elements found in the production of this traditional pottery can not only explain its cultural value but also showcases the functional utility and the important role it plays in developing the economy of kuron pottery in Sabah. This can become a source of income and contribute in generating the country's economy.
\end{abstract}

Key words: Women, Economy, Traditional Pottery, Feminism, Icon.

\section{INTRODUCTION}

The role of women today is getting more evident in various aspects which are in line with a country's development. The duties and functions of women are undisputed because of the roles they had played and their many contributions that have become iconic in many countries [1]. This proves that the quality of work that women do is equal to that done by men. In fact women can do more than that, whether in their careers, taking care of their children, cooking or managing their families. Before this, women were considered weak and unable to perform the same work as men do [2]. This has resulted in women's freedom of speech and expressing their point of view being oppressed and denied. However the success of women in economic development has proven that they are an important asset that plays an important role in the development of a country [3].

The role of women has become more important in an increasingly developed nation. Women's rights have been defended and protected. The role of working women in upgrading the economy is consistently being respected and rewarded by the government as well as private sector employers. Most women now are working outside their homes. Their roles are no longer confined to being homemakers, mothers and wives but in various fields of occupation. For example, in the context of kuron pottery production in Sabah which is entirely dominated by women. So with this, women are icons in developing the small pottery industry in Sabah.

Historically pottery arts in Sabah is one of the oldest which dates back to the Neolithic age. Usually the ancient remains of pottery are found in caves, rock dwellings and river banks. Based on a study by Barbara Harrison [4], it states that pottery is a valuable heritage landmark in the island of Borneo which is primarily produced by women. Therefore a study is conducted to explore the beauty and design characteristics of traditional Sabah pottery is created by women.

Corresponding Author: Nurul Aisyah Othman, PhD, Borneo Heritage Unit Research, University Malaysia Sabah, 019974 4597 
Traditional pottery is also one of the key elements in the ceramic manufacturing industry which needs to be explored and appreciated. It is a heritage that reflects the identity and culture of the tribe that created it. Therefore a study on women icon and the traditional pottery in terms of the processing production and the exploration if its beauty, design and motifs is needed. Through this documentation the traditional pottery is maintained as a treasure and cultural heritage of the community.

\section{ECONOMIC DEVELOPMENT OF SABAHAN POTTERY}

The majority of crafts person working in the traditional pottery industry in Sabah are made up of local women who have inherited the skills from previous generations [5]. They are very knowledgeable in the basics of their skills. Their knowledge encompasses the selection of raw materials which is clay and the shaping and quality control to ensure it does not break easily. They also inherit skills which determine the uniqueness of a product which is based on the use of beautiful colors through a mixture of natural resources. This knowledge is an important criterion among these pottery crafts by women to ensure that their products are made to the highest quality and standard.

Traditional Sabahan pottery in the context of its design and motifs has a high significance in their traditional lives [6]. For example the creation design shows a high degree of ideological and creative thought process. The design of the crafts women in terms of patterns and motifs are usually based on the natural surroundings and their daily lives. Therefore the production of traditional pottery is not only for utility purposes, it also reflects the thoughts and philosophies of past generations. The Malaysian Handicraft Development Corporation has recognized kuron among the Kadazan Dusun community as a symbol or icon of the traditional pottery manufacturing industry of Sabah.

Among the functions of the kuron pot is as utensil for cooking food, which also relates to a women's work. Cone-shaped kuron pots are used for cooking rice and boiling water. According to traditional beliefs the kuron pot contains certain nutritional properties which can help cure various kinds of illnesses after drinking water boiled from it. In terms of production, the shaping of its design and patterns shows the aesthetical ideas inspired by the kuron pottery craftswomen.

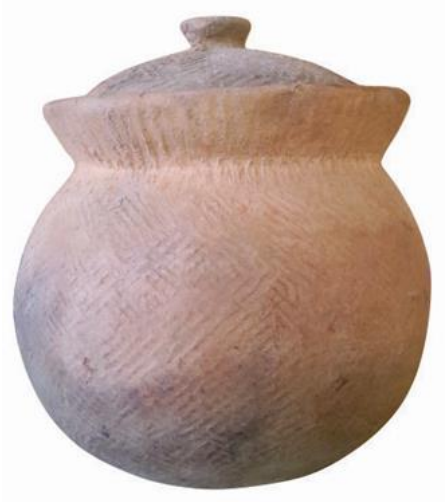

Figure 1: Image of kuron pottery.

The study of traditional pottery of Sabah explores the role of women in displaying the beauty of design and ornamentation in context of its small industry. The role of women in boosting the production of pottery also enhances the economic status of families and communities. Traditional pottery is an ethnic treasure and has the potential to create a unique industry which can compete with the rest of the world. A study on the role of women and manufacturing techniques as well as the aesthetical values in the art of traditional pottery making is a prelude to an era of innovative ceramic products that can be developed as an economic generator.

\section{RESEARCH METHODOLOGY}

In this study, the researcher uses a qualitative-based ethnographic approach that is used as a guideline to obtain first and end-to-end data by being directly involved in the field recording information and conducting interviews. During the preliminary stage of data gathering the researchers will be involved directly in analyzing the aesthetic value found in the production, design and motifs of Kuron pottery by linking the role of women in contributing to the development of ceramic economics from the feminist theory point of view presented by June Hannam [5]. According to June Hannam, the role of women or women's rights nowadays is equal to that of men in terms of contribution in the economic and social perspective. It can be seen that the role of women is expedient and lends assistance to men and also contributes to the economic development with the production of Sabah's Kuron pottery that is produced with attractive designs, and aesthetic and functional motifs. These handicraft products also indirectly contribute to increase the profile of the 
ceramics industry of Malaysia through the sales and demonstration of handicraft products often organized by the Malaysian Handicraft Development Corporation.

\section{WOMEN AS ICONS IN THE POTTERY MAKING INDUSTRY IN SABAH}

The increasing demand for handicraft products in Malaysia today has influenced the personality development of handicraft entrepreneurs' innovation, commitment, as well as the ability to succeed in their business. In fact, Einarsson [7] also notes that the development of the handicraft industry in several Southeast Asian countries is amongst the most important contributors to the development of the personality of an entrepreneur and the Gross Domestic Product (GDP). Whereas in the context of marketing, Lamb et al [8] makes it clear that the demand for a product and service in the market today depends on it fulfilling the needs and requirements of consumers. Therefore, to increase the demand for handicraft products and fulfilling the needs of the consumer community today, handicraft entrepreneurs need to be innovative and committed in the business to develop handicraft products that still retain its ethical and aesthetic values of the Malay culture. Without doubt, the handicraft industry needs new innovation and ideas in all aspects to ensure the production of quality and acceptable products for consumers.

Kuron pottery made by the ethnic Dusun Tindal tribe from Malangkap village has its special features created from traditional technique and manufacturing process. Its structure and design has been created based on its functions and uses, for example cooking utensils, food storage containers and ritual tools [9]. Figure 2 shows the creativity of a woman in producing traditional kuron pottery using handicraft skills. The craftsmanship of the pottery was transformed into creative design features and has successfully maintained an appeal to local demand. This small industry contributes towards additional family income and local economy through open craft sales and has high demand for use as cooking utensil, jewelry and uses in traditional rituals, dances and ceremonies [8]. Nowadays though, the functions of this have shifted with the modern era, its design and motifs are still preserved and have not changed or conformed to modernization. This is because it still retains the identity and heritage of their ancestors. The following shows the kuron design structure.

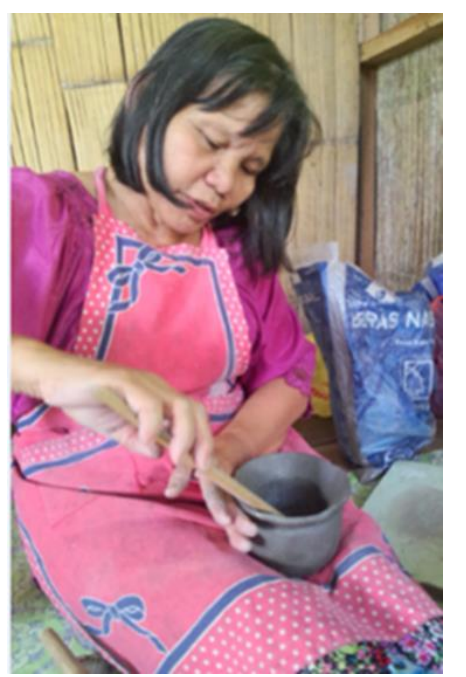

Figure 2: Woman making traditional kuron pottery.

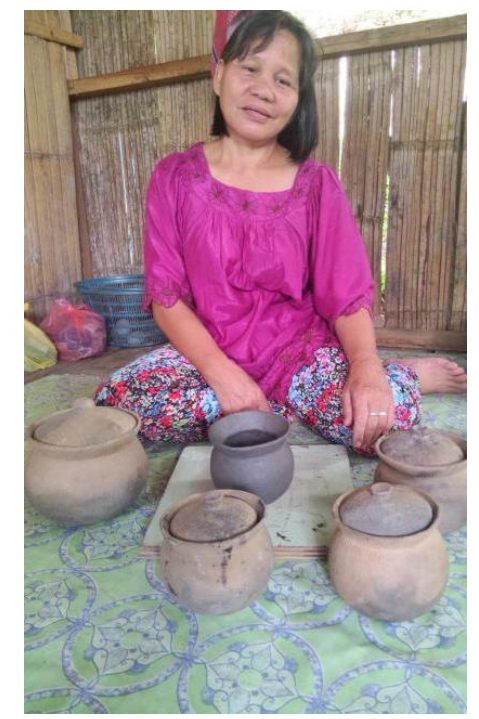

Figure 3 : Various saizes of kuron and popogong

Kantiam Binti Setan (60 years old) [11], is a craftswoman of kuron pottery from the village of Malangkap Tiong, Kota Belud, Sabah. There are two types of kuron pottery produced, namely kuron and popogong and is mainly produced by the ethnic Dusun Tindal tribe in the village. Both types of pottery have different functions and sizes (Figure 3). Larger kuron pots are used as cooking utensils and for storing foods. Smaller popogong pots are mainly used as ritual and dance tools. According to information provided these two type of pottery have received a warm welcome in the local markets or during traditional festivals and ritual ceremonies. It is in high demand from foreign as well as locals tourists. 
This high demand is significant with its traditional technique of production and pattern design that creates its own uniqueness. More significant is the belief that drinking water from the kuron pot can cure body ailments and lowers high body temperatures. The constant demand for this pottery shows a high potential in the ceramics industry. The popogong are used according to modernity as they are instrumental in accompanying various ethnic Dusun Tindal dances [12]. The symbolism behind popogong pottery demonstrates these iconic women which is of the Dusun Tindal ethnic tribe to the outside world for their high level of creativity and wisdom in producing handicraft products that can be used for various functions. Figure 4 shows the use of kuron and Figure 5 shows the procedures of using the popogong in Sabah.

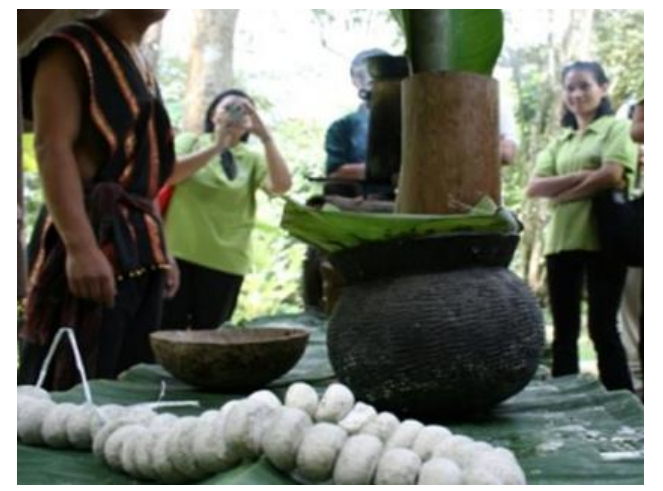

Figure 4: Kuron pottery used in a ritual ceremony.

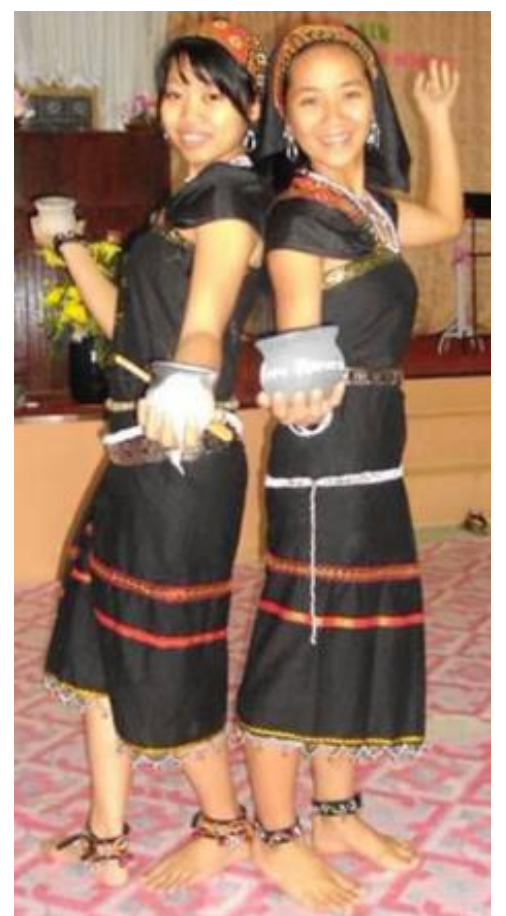

Figure 5: Popogong used in momorun kuron dance.

\section{KURON POTTERY MANUFACTURING DEMONSTRATION}

Beside, kuron pottery production is traditionally used. Mrs kantiam also have kuron production workshops pottery to various society layer group level that are interested to learn tradisonal handicraft heritage. Sabah kuron pottery handicraft heritage should be carried and make lasting by all corporation level one of them through move like have demonstration like this should in spread to people. Every time Mrs Kantiam's pottery workshop school holiday season frequented by school students and students from University Malaysia Sabah (UMS) to learn get-up and inquisitive by further on the traditional pottery craft goods. Beginning from land acquisition way until impurity discharge process in the ground and until pottery production than one process to one process shown one by one clearly and detailed. Figure 6 (i) and (ii) shows as through good action like this carried out by Kantiam able giving various benefits to $\mathrm{Y}$ generation and $\mathrm{X}$ nowadays so that their free time fill up with activity that is beneficial and conserve tradisonal craft heritage that getting forgotten.

(i)

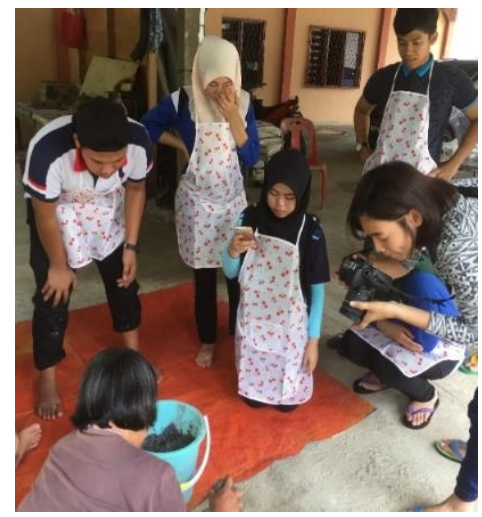

(ii)

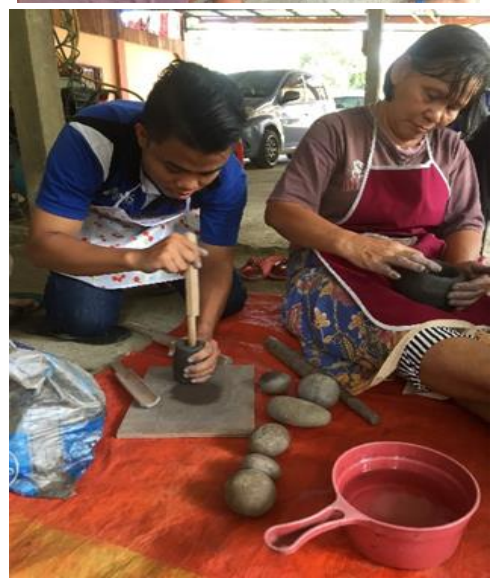

Figure 6: Demonstration of making pottery to UMS student. 


\section{CONCLUSION}

The researcher discovered that the Dusun Tindal ethnic community has many traditional cultures that are still being practiced today despite the differences in environment and culture. This is seen in the process of making traditional kuron pottery crafts which symbolizes the values of each cultural identity through traditionally produced handicrafts [13]. The researchers have seen the process of making this traditional pottery by the craftswomen and experienced the difficulties of producing them. However, the beauty and uniqueness of the cultures that produce traditional pottery can be seen through the effort and hard work of these women in the creation of such pottery. Women icons in the manufacturing of traditional pottery are also still practiced and kept up to date. Additionally, the study of pottery chosen from the Dusun Tindal community showcases the craftsmanship skill level among these intelligent women in producing crafts that has become an icon of economic development in the local community. The government and the private sectors should be more involved in their roles in helping women in developing the ceramic craft industry to facilitate in the continuing progress of the pottery craft industry.

\section{REFERENCES}

[1] Sr Philomena D souza, Fma. (2005). Women Icon of Liberation. Mumbai: Better Your self Books.

[2] Abdul Rahman Abdul Aziz. (2014). Demokrasi di Malaysia. Kuala Lumpur: Institut Terjemahan Buku Malaysia.
[3] Azlina Abu Bakar. (2012). Psikologi Industri dan Pengurusan Sumber Manusia. Kuala Terengganu: Universiti Malaysia Terengganu.

[4] Barbara V. Harrison. (1986). Pusaka: Heirloom Jars of Borneo. Singapore: Oxford University Press.

[5] June Hannam. (2007). Feminism. London: Pearson Education.

[6] Ismail Haji Ibrahim dan Jane Wong Kon Ling. (2002).Warisan Seni dan Etnik Sabah. Kota Kinabalu: Pusat Penataran Ilmu dan Bahasa Universiti Malaysia Sabah.

[7] Einarsson, A. (2002). Entrepreneurship as a Part of the Creative Industries within the Cultural Sector in a Small Society. Review of International Comparative Management, 1(13), 208-229.

[8] Lamb, C.W., Hair, J.F., McDaniel, C. (2004), Marketing. 7th ed. Oxford: Oxford University Press

[9] Perbadanan Kemajuan Kraftangan Malaysia. (2005). Buku Tembikar Tradisional: Edisi Pertama. Perbadanan Kemajuan Kraftangan Malaysia.

[10] Anne D' Alleva. (2012). Method \& Theories of Art History. United Kingdom: Laurence King Publishing Ltd.

[11] Kantiam Binti Setan, 60 years, pottery making at Kampung Melangkap Kapa Kota Belud, Sabah. Interview date 22 March 2016.

[12] Konsimin Binti Dalani, 56 years, pottery keeper at Kampung Tuguson Kota Belud, Sabah. Interview 26 March 2016.

[13] Shamsiah Binti Soupi. 42 years, pottery making at Kampung Melangkap Kapa Kota Belud, Sabah. Interview 24 May 2015. 